\title{
Epigenetic drug 5-azacytidine impairs the potential for odontogenesis but improves tooth morphogenesis in the transplanted embryonic mandible
}

\author{
VEDRAN RADUJKOVIĆ ${ }^{1,2}$ \\ MARTA HIMELREICH-PERIĆ 3,4 \\ MARTA TAKAHASHI ${ }^{2}$ \\ NINO SINČIĆ3,4 \\ ANA KATUŠIĆ BOJANAC ${ }^{3,4}$ \\ DAVOR JEŽEK 2,4 \\ GORDANA JURIĆ-LEKIĆ2,4 \\ FLORIANA BULIĆ-JAKUŠ ${ }^{3,4}$ \\ ${ }^{1}$ Community Healthcare Centre "Zagreb-Centar", \\ Zagreb, Croatia \\ ${ }^{2}$ Department of Histology and Embryology, School of \\ Medicine, Zagreb, Croatia \\ ${ }^{3}$ University of Zagreb, School of Medicine, Department \\ of Medical Biology, Zagreb, Croatia \\ ${ }^{4}$ Centre of Excellence for Reproductive and \\ Regenerative Medicine, Unit for Biomedical \\ Investigation of Reproduction and Development, \\ School of Medicine, University of Zagreb, Zagreb, \\ Croatia \\ Running title: Influence of a DNA demethylating \\ agent on transplanted embryonic mandible

\section{Correspondance:} \\ Marta Himelreich-Perić \\ E-mail address: marta.himelreich@mef.hr

\section{List of abbreviations: \\ 5azaC - 5-azacytidine \\ BMP - bone morphogenic protein \\ FGF - fibroblast growth factor \\ HERS - Hertwig's epithelial root sheath \\ HOX - homeobox (gene) \\ i.p. - intra-peritoneal \\ MSX1 - muscle segment homeobox 1 \\ MSX2U - muscle segment homeobox $2 \mathrm{U}$ \\ PBS - phosphate-buffered saline \\ PCNA - proliferating cell nuclear antigen \\ SHH - sonic hedgehog protein \\ WNT - Wingless-related integration site}

Keywords: tooth; anomalies; Vidaza; embryo; grafting; epigenetics; DNA-methylation

Received April, 16, 2020

Revised April 30, 2020

Accepted April 30, 2020

\section{ABSTRACT}

Background and purpose: Epigenetic mechanisms are crucial in regulating development. The aim of the study was to investigate whether a DNAdemethylation drug 5-azacytidine ( $5 a z a C)$ affects odontogenesis in embryonic mandibles ectopically transplanted in vivo.

Materials and methods: Mandibles from 13.5- and 14.5-day-old Fischer rat embryos containing early tooth-primordia (dental laminas) were transplanted under the kidney capsule of adult males. Host animals were treated with $5 \mathrm{azaC}(5 \mathrm{mg} / \mathrm{kg}$, i.p.) for the first three days and sham-controls with PBS. After two weeks, differentiation was analysed by histology and cell proliferation by immunohistochemistry.

Results: In some transplants, the bell stage of incisors and molars developed. Teeth in 13.5-day-old transplants produced only dentine, and the incidence of mandibles with teeth in 5 azaC-treated hosts was lower. PCNA was expressed only in odontoblasts. Several 14.5-day-old transplants developed teeth with both dentine and enamel. In 5 azaC-treated hosts, Hertwig's epithelial root sheath developed, but the number of mandibles with teeth was lower than in controls $(p<0.05)$. Somewhat fewer molars than incisors developed under 5azaC-treatment. Differentiation of the bone, cartilage, salivary glands, epidermis, hair, sebaceous glands, and adipose cells proceeded in all transplants, except for myotubes that were absent from older transplanted mandibles.

Conclusions: Embryonic mandibles retained the potential for the development of teeth at the ectopic site, but odontogenesis was more advanced in a-day-older mandibles. In older mandibles, the 5-azaC impaired potential for odontogenesis, but teeth that developed reached a higher stage of organogenesis. These results are contributing to the epigenetic explanation of the development of teeth anomalies.

\section{INTRODUCTION}

$\mathrm{C}$ mbryonic development depends on the coherent interaction of ge-

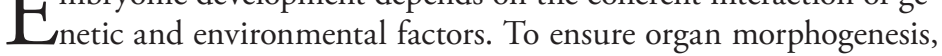
control mechanisms, such as the embryonic induction based on the interaction of different cells, regulated cell migration, precisely regulated proliferation, and programmed cell-death (apoptosis) are activated during specific phases of development $(1,2)$.

Tooth development is a classic example of an epithelial-mesenchymal interaction of ectodermal origin. Regulation of tooth positioning from 
incisors to molars is achieved through HOX-gene expression in the mesenchyme. The development of each dental lamina to the dental bud phase is regulated by the epithelium and then by mesenchyme. The signals that control dental development are growth factors Wnt, bone morphogenetic proteins (BMP), fibroblast growth factors (FGF), and sonic hedgehog protein (SHH). Transcriptional factors MSX1 and MSX2U also take part in the process of cell differentiation and modelling of each tooth. Teeth have a signalling centre that organizes dental development, precisely the enamel knot. It is formed as a limited area in the enamel epithelial layer at the top of the dental bud. At the transition from the early cap to the bell stage, the enamel knot cells degenerate by apoptosis, which is strictly regulated by BMP4 (3-5). Unlike some other mammalian species, rats have only incisors and molars. Their incisors have deep roots, three layers (pulp, dentin and enamel only on the front side of the incisors) and they grow continuously (6).

The environment influences proper gene expression necessary for development through epigenetic mechanisms (7), among which the DNA methylation process, one of the key epigenetic mechanisms in vertebrates $(8$, 9). DNA methylation modulates gene expression by influencing DNA transcription and changing the response of cells to external stress $(10,11)$. A rare study on patients with impaired odontogenesis (non-syndromic anodontia and hypodontia) showed higher global methylation level and simultaneous methylation level change of multiple developmentally important gene promoters (12).

Ectopic transplantation of embryos or its parts is an optimal method for investigating the remaining developmental potential for growth and differentiation of various embryonic cell types, tissues or organs, freshly isolated or pre-cultivated in vitro $(13,14)$. In organ-transplants, the crosstalk between organ primordia and the surrounding microenvironment necessary for organogenesis is possible also because the main interactions regulating normal development are spared. Even in the transplants of early rodent embryos that develop into experimental embryonal teratoma-tumors consisting mainly of differentiated tissues in anatomically irregular spatial relations, sometimes the development of organotypic structures, like teeth or fingers with falangae were described $(15,16)$. Such experimental tumors can develop in different extrauterine positions, such as testis (17), anterior chamber of the eye (18), under the kidney capsule (19), subcutaneous connective tissue (20) or back muscles (21).

Among ectopic sites, the subcapsular space of the kidney seems to be the optimal one according to the vast experience of the Zagreb School of Mammalian Embryology and other authors, because the transplanted tissue develops between the vascularised kidney capsule and the kidney parenchyma, where the vascularisation ensures proper nutrition of transplants that are stably positioned in a subcapsular pocket. Vascularization also ensures delivery of extraneous agents applied to the host for research purposes. Cultivation under the kidney capsule was performed with embryos-proper, lentectomised eye cup, neural retina (18, 19), while transplantation of tooth germs (22), lachrymal gland (23) gonads (24) and epiglottis (25) followed.

5 -azacytidine (5azaC) is a DNA-demethylating epigenetic drug used for the treatment of myelodysplastic syndrome and leukemias in humans. Changing the DNA methylation, it causes teratogenic effects during mammalian development $(26,27)$ and also influences the development of organ primordia cultivated in vitro or transplanted to the ectopic environment under the kidney capsule $(25,28)$.

The aim of this study was to determine the potential for tooth organogenesis under the influence of the DNAdemethylating epigenetic drug $5 \mathrm{azaC}$ in the fetal rat mandible transplants containing the dental lamina as the basis for tooth development.

\section{MATERIAL AND METHODS}

All procedures on animals were conducted according to the Directive 2010/63/EU and Croatian Law on protection of experimental animals with approval from the Ethics Committee of the School of Medicine, University of Zagreb.

\section{Animals}

Females of the Fisher strain rats were mated with the males in the evening. The next morning, a finding of the sperm in the vaginal smear designated the beginning of pregnancy (0.5-day-old embryos). Animals were anesthetized with $0.8 \mathrm{ml} / \mathrm{kg}$ of ketamine (Narketan'; Vétoquinol, Bern, Switzerland) and $0.6 \mathrm{ml} / \mathrm{kg}$ of xylazine (Xylapan; Vétoquinol, Bern, Switzerland) and uteruses were removed. From embryos recovered at 13.5 and 14.5 days of gestation, mandibles were isolated by microdissection under the dissecting microscope.

\section{Transplantation}

Mandibles were transplanted under the kidney capsule of the 3-month-old male rats of the same strain. To approach the kidney, a paravertebral incision through muscle and skin was done after the rats were anesthetized with $0.8 \mathrm{ml} / \mathrm{kg}$ of ketamine (Narketan'; Vétoquinol, Bern, Switzerland) and $0.6 \mathrm{ml} / \mathrm{kg}$ of xylazine (Xylapan'; Vétoquinol, Bern, Switzerland). A small pocket was formed after the incision of the kidney capsule, and the mandible was transplanted. Michael's clumps $(16 \mathrm{~mm})$ were used to close the wound.

5 -azacytidine $(5 \mathrm{mg} / \mathrm{kg}$; Sigma Aldrich, St. Louis, MO, USA) was applied by the i.p. injection during three consecutive days, while controls were treated with PBS. After 14 days, host animals were sacrificed with $0.8 \mathrm{ml} /$ 
$\mathrm{kg}$ of ketamine (Narketan ${ }^{\oplus}$; Vétoquinol, Bern, Switzerland) and $0.6 \mathrm{ml} / \mathrm{kg}$ of xylazine (Xylapan ${ }^{\circledR}$; Vétoquinol, Bern, Switzerland). The transplants were then microsurgically isolated under a dissecting microscope, using watchmaker's forceps.

\section{Histology and immunohistochemistry}

Isolated transplants were fixed in the Saint Marie solution $\left(+4{ }^{\circ} \mathrm{C}, 96 \%\right.$ ethanol, and $1 \%$ acetic acid added directly before fixing), rinsed, dehydrated and embedded in paraffin. Uninterrupted $5 \mu \mathrm{m}$ serial sections were routinely prepared for light microscopy and stained with hematoxylin and eosin or Masson's trichrome staining (29).

For immunohistochemical analysis, the tissue was deparaffinised and rehydrated in xylene ( $2 \times 5$ minutes), absolute and $96 \%$ ethanol ( $2 \times 3$ minutes), and $\mathrm{H}_{2} \mathrm{O}(0.5$ minutes). Sections were then placed in a covered jar with buffer solution (containing Tris- $\mathrm{HCl}$ and distilled $\mathrm{H}_{2} \mathrm{O}$ ) and heated in a microwave oven ( 9 minutes at $620 \mathrm{~W}$ and 11 minutes at $310 \mathrm{~W})$. After that, the sections were cooled in the buffer solution for 40 minutes at room temperature and then in distilled $\mathrm{H}_{2} \mathrm{O}$ for 10 minutes.
Monoclonal mouse anti-proliferating cell nuclear antigen (PCNA) (Clone PC 10, Code No. M 0879, DAKO, Agilent, USA), 1:100 was applied for 1 hour. As a negative control, the standard negative control reagent (Code No. V 1617, DAKO, Agilent, USA; $7 \mathrm{ml}$ mouse IgG1 in 0.05 $\mathrm{M}$ Tris buffer, $\mathrm{pH} 7.6$, containing carrier protein and $15 \mathrm{mM}$ sodium azide) was used. DAKO Animal Research kit, peroxidase (Code no. K 3954, DAKO, Agilent, USA) accordingly to the manufacturer's instructions, was used for visualization of the PCNA signal.

\section{Statistical analysis}

Statistical analysis was performed using SPSS 20.0 software (IBM SPSS Inc. Chicago, IL, USA). All measurements were taken in triplicate. The critical significance level for the statistical tests performed was set at 0.05 . Results were statistically evaluated by Fisher's exact test.

\section{RESULTS}

To analyse the impact of the ectopic environment and the epigenetic influence of 5-azacytidine (5azaC) upon
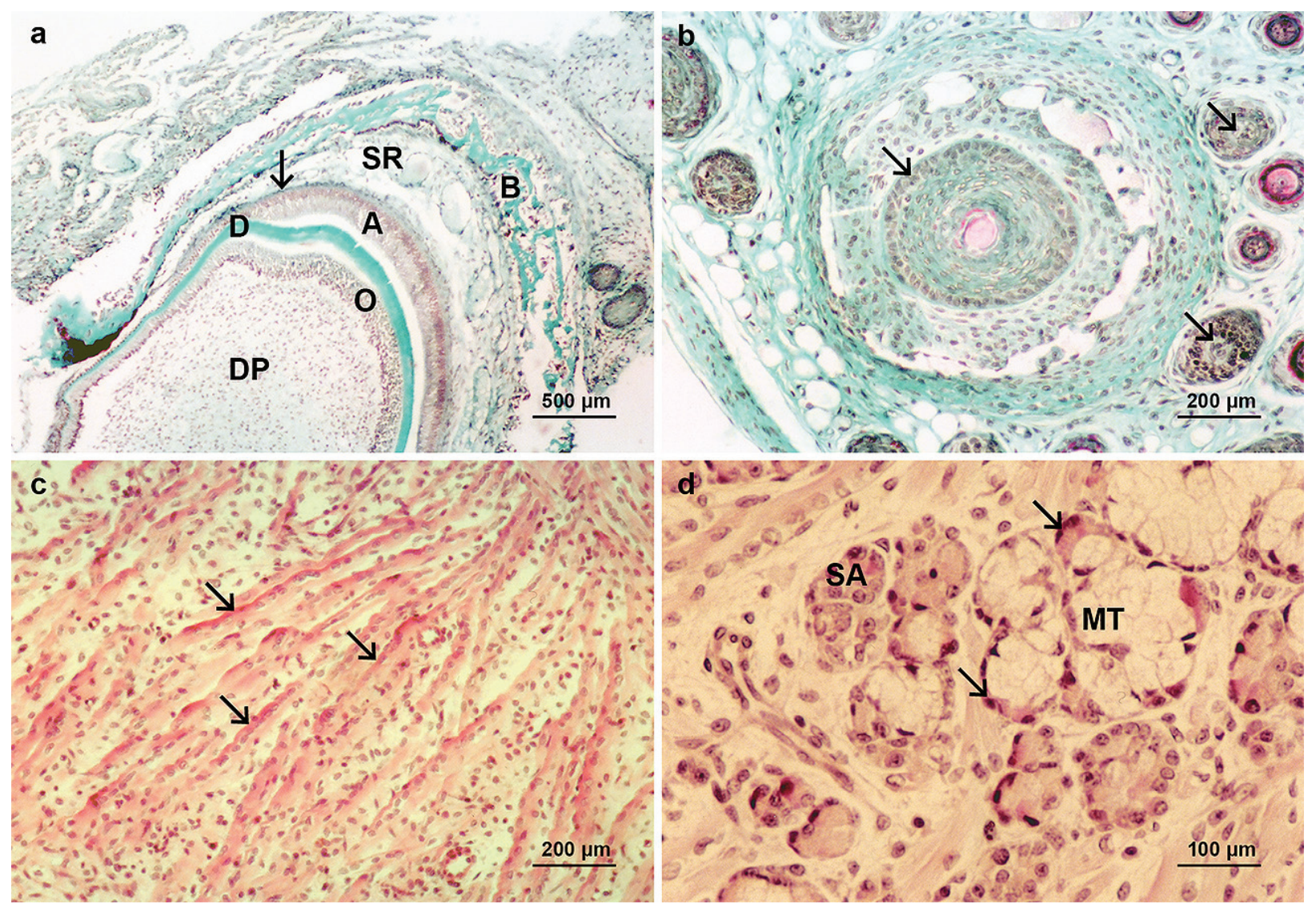

Figure 1. Control 13.5-day old rat embryonic mandible transplant after 14 days. A-ameloblasts, D-dentin, DP-dental papilla, Oodontoblasts, SR-stellate reticulum, SA-serous acini, MT-mucous tubules, B-bone. a) incisor germ, stratum intermedium of the stellate reticulum (arrow), Masson's trichrome staining, b) well differentiated hair follicles (arrows), Masson's trichrome staining, c) myotubes (arrows), $H+$ $E, d)$ mixed salivary glands, serous demilunes (arrows), $H+E$. 
odontogenesis in embryonic mandibles, they were transplanted under the kidney capsule, and host animals were treated by PBS (controls) or by the DNA demethylating agent $5 \mathrm{azaC}$. To find out whether the development was influenced stage-specifically, mandibles from two earliest consecutive stages were used.

\section{Histological analysis of the 13.5-days old mandibular transplants}

After two weeks, odontogenesis was discovered in all control transplants. Both molars and incisors (Figure 1a) differentiated to the bell stage. Odontoblasts secreted a thin layer of dentin, but ameloblasts did not secrete any enamel. Odontoblasts expressed proliferating cell nuclear antigen (PCNA) in their nuclei, while PCNA expression was absent from ameloblasts (Figure 3). Other histological structures that developed in these mandibular transplants were bone (Figure 1a), cartilage, myotubes (Figure 1c), salivary glands (Figure 1d), epidermis, hair follicles (Figure 1b), sebaceous glands and adipose cells.

All transplants, growing in animals that were treated with $5 \mathrm{azaC}$, survived under the kidney capsule and were similar in size after the experimental period of 14 days. Histological analysis showed similar results as in controls. Molars and incisors differentiated to the bell stage. In the stellate reticulum, stratum intermedium was visible (Figures $2 \mathrm{a}$ and 2c). Again, secretion of dentine, but not of enamel, was found, and other histological structures developed such as the bone, cartilage (Figure 2d), myotubes, salivary glands (Figure 2b), epidermis, hair follicles, sebaceous glands, and adipose cells. Intranuclear expression of the PCNA was present in a few odontoblasts but was absent from ameloblasts (Figure 3).

\section{Histological analysis of the 14.5-days old mandibular transplants.}

All transplants in the control group contained molars and incisors (Table 1) that differentiated to the bell stage. In contrast to the teeth found in 13.5-days old mandibular transplants, 14.5 -days old mandibular transplants produced both enamel and dentin (Figure 4), and Tome's processes were noticeable (Figure 4e). The stratum intermedium of the stellate reticulum was visible in all teeth (Figure 4). Other histological structures that developed
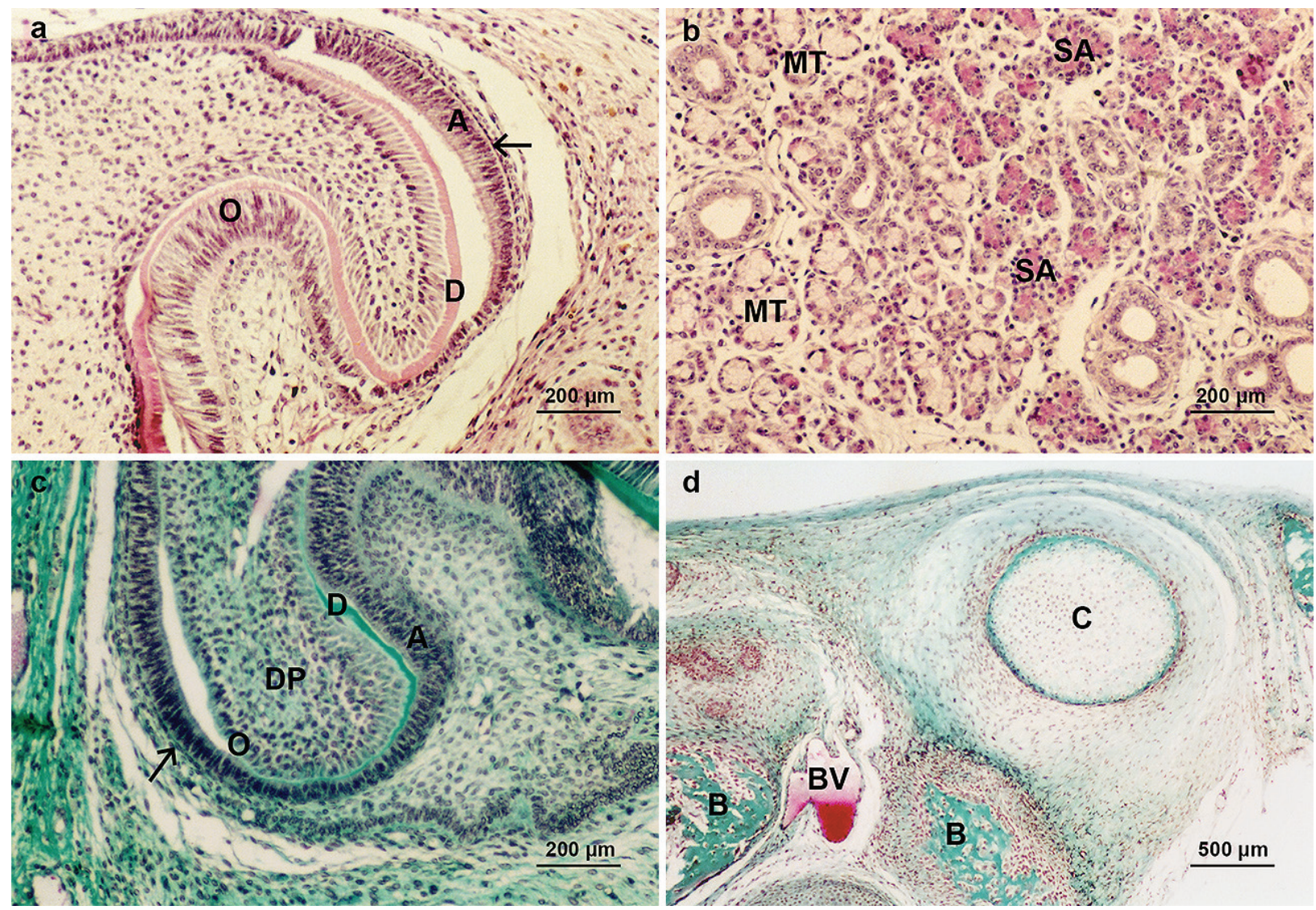

Figure 2. 13.5-day old rat embryonic mandible transplant from adult hosts treated with 5azaC for 14 days. A-ameloblasts, Ddentin, DP-dental papilla, O-odontoblasts, B-bone, BV-blood vessel, SA serous acini, MT-mucous tubules, stratum intermedium of the stellate reticulum (arrow). a) a bell stage tooth, $H+E, b)$ mixed salivary glands, $H+E, c)$ bell stage tooth, Masson's trichrome staining, d) embryonic mandible, Masson's trichrome staining. 

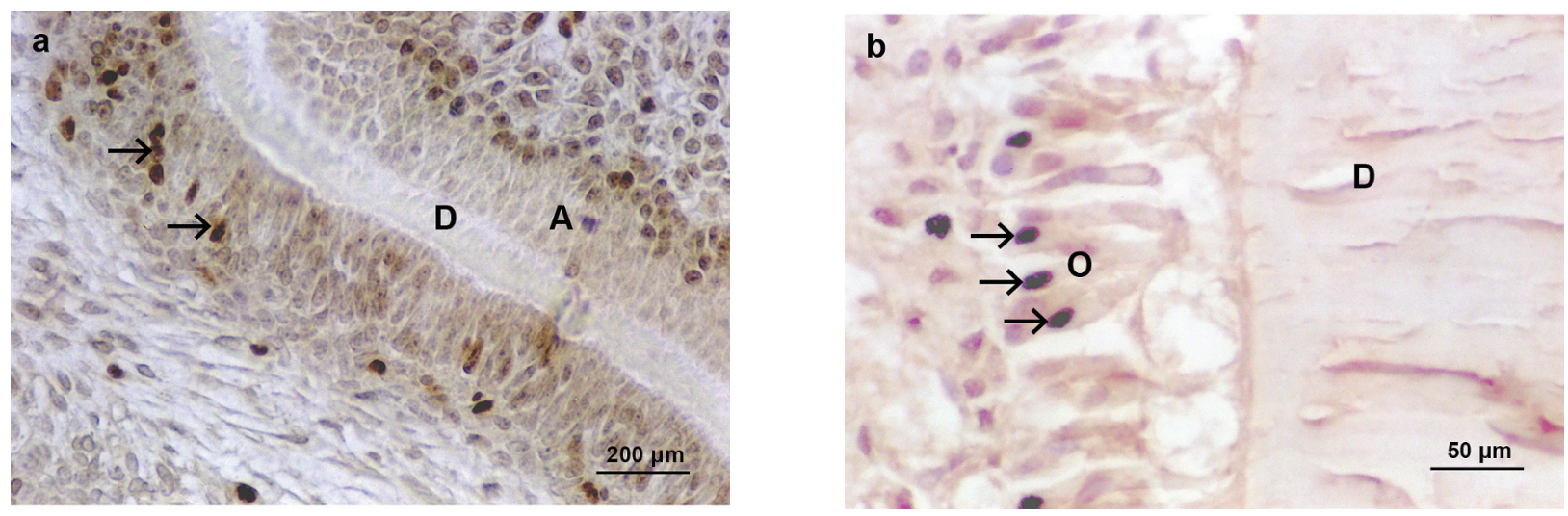

Figure 3. Control 13.5-day old rat embryonic mandible transplant from adult hosts after 14 days. PCNA expression in odontoblasts (arrows), A-ameloblasts, $O$-odontoblasts, $D$-dentin. DAB, haematoxylin counterstain. a) treatment with 5 aza $C$, b) control.

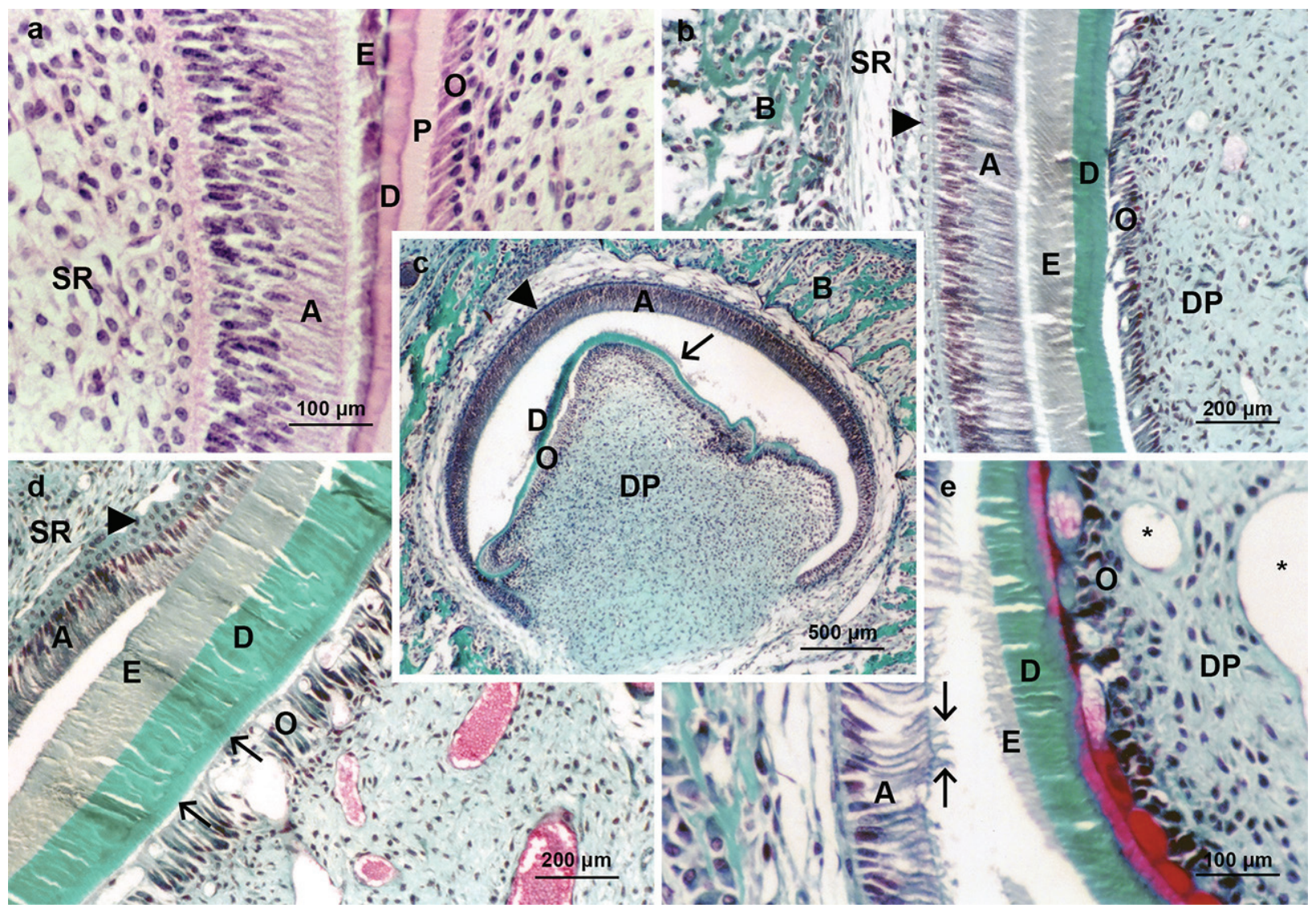

Figure 4. Control 14.5-day old rat embryonic mandible from adult bosts after 14 days. DP-dental papilla, O-odontoblasts, A-ameloblasts, $D$-dentin, P-predentin, SR-stellate reticulum, B-bone, E-enamel. a) dental crown, $H+E$, b) dentino-enamel junction, stratum intermedium of the stellate reticulum (arrowhead) Masson's trichrome staining, $\boldsymbol{c}$ ) tooth germ, enamel (arrow), stratum intermedium of the stellate reticulum (arrowhead), Masson's trichrome staining, d) dental crown, stratum intermedium of the stellate reticulum (arrowhead), predentin (arrows), Masson's trichrome staining, e) bell stage tooth, Tome's processes (arrows), blood vessels (asterisk), Masson's trichrome staining.

in transplants were bone, cartilage, salivary glands, epidermis, hair follicles, sebaceous glands, and adipose cells.

All mandibular transplants which were treated with $5 \mathrm{azaC}$ survived under the kidney capsule and were simi- lar in size after the experimental period of 14 days. Incisors and molars differentiated to the bell stage. In one of the developing teeth, only dentin was found (Figure 5a), while in all of the rest, both dentin and enamel were pro- 
Table 1. Odontogenesis in rat embryonic mandible-transplants from hosts treated with $5 a z a C$ for 3 consecutive day. Number of transplants (N) and percentage of transplants with developed teeth, molar, and incisor.

\begin{tabular}{|c|c|c|c|c|c|c|c|c|}
\hline \multirow[t]{2}{*}{ Age } & \multicolumn{2}{|c|}{$\underset{N}{\text { Group }}(\mathrm{N})$} & \multicolumn{2}{|c|}{ Teeth } & \multicolumn{2}{|c|}{ Molar } & \multicolumn{2}{|c|}{ Incisor } \\
\hline & & & $\%$ & $\mathrm{~N}$ & $\%$ & $\mathrm{~N}$ & $\%$ & \\
\hline \multirow[t]{2}{*}{13.5 days } & $5 \mathrm{azaC}$ & (7) & 2 & 28 & 1 & 14 & 2 & 28 \\
\hline & Control & (8) & 5 & 71 & 4 & 50 & 2 & 25 \\
\hline \multirow[t]{2}{*}{14.5 days } & $5 \mathrm{azaC}$ & (7) & $3^{*}$ & 42 & 1 & 14 & 3 & 32 \\
\hline & Control & (7) & $7^{*}$ & 100 & 4 & 57 & 4 & 57 \\
\hline
\end{tabular}

${ }^{*} \mathrm{p}=0.035$ (Fisher's exact test)

duced (Figure 5c). The stellate reticulum clearly shows stratum intermedium (Figure 5a), but only in this group, all developing teeth showed the Hertwig's epithelial root sheath (HERS) (Figure 5d). Among other histological structures, bone (Figure 5a), cartilage (Figure 5e), salivary glands, epidermis, hair follicles (Figure 5b), sebaceous glands, and adipose cells were assessed.

\section{Comparison of the tooth incidence between treated with 5azac and controls}

To assess the influence of $5 \mathrm{azaC}$ on developmental processes, we conducted a comparison of the incidence of the main histologically analysed structures between the experimental and control groups of mandibular trans-
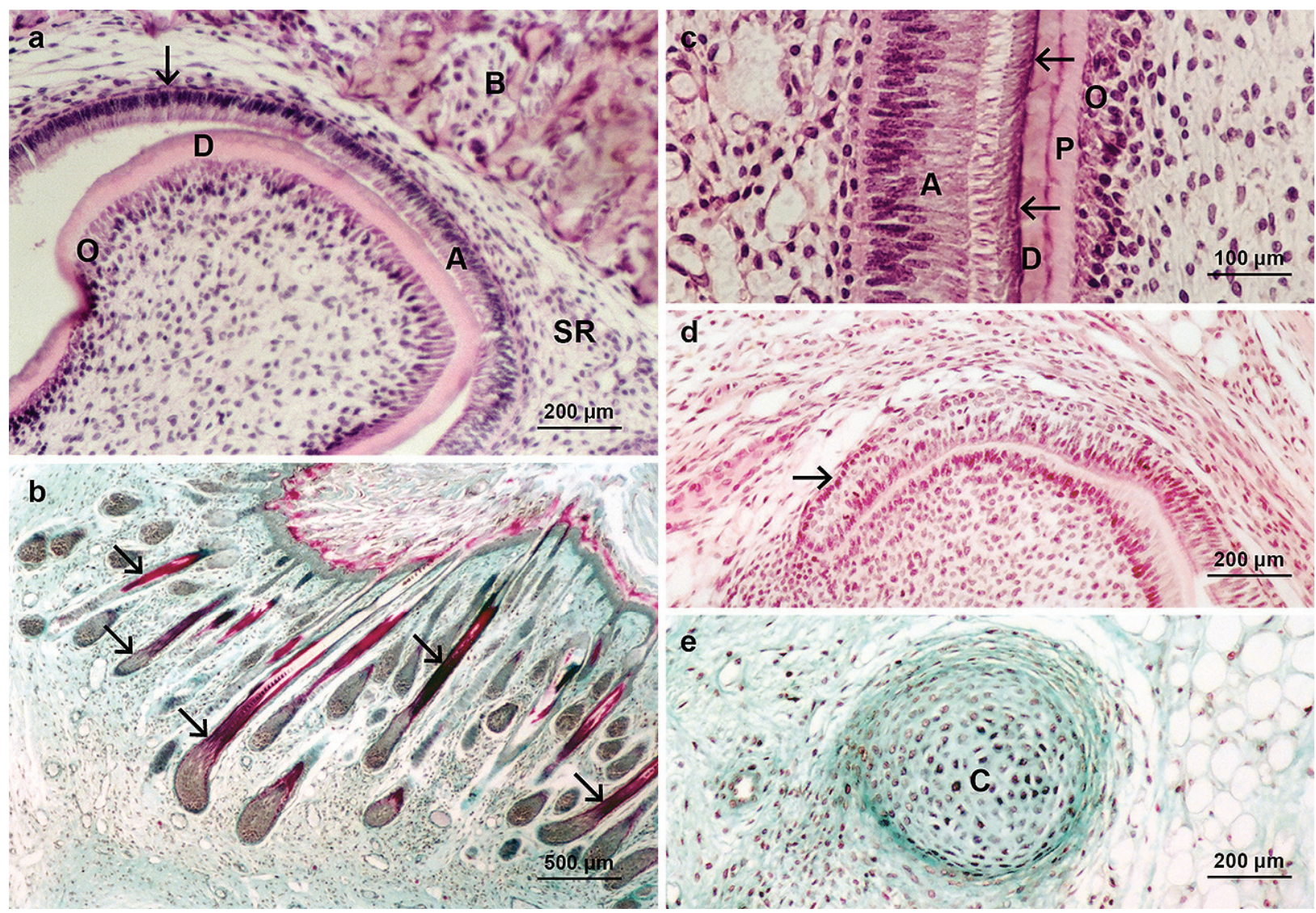

Figure 5. 14.5-day old rat embryonic mandible from adult hosts treated with 5azaC after 14 days. O-odontoblasts, D-dentin, Aameloblasts, SR-stellate reticulum, B-bone, P-predentin, $C$-cartilage. a) bell stage tooth, stratum intermedium of the stellate reticulum (arrow), $H+E, b)$ hair follicles (arrows), Masson's trichrome staining, c) dentino-enamel junction, enamel (arrow), $H+E$, d) Hertwig's epithelial root sheath (arrow), $H+E$, e) cartilage, Masson's trichrome staining. 
Table 2. Differentiation of histological structures other than teeth, in 13.5-and 14.5-day-old rat embryo mandible transplants under 5azaC treatment. Number of transplants $(N)$ and percentage of differentiated structures in transplants.

\begin{tabular}{|c|c|c|c|c|c|c|c|c|}
\hline \multirow{3}{*}{\begin{tabular}{|l} 
Age \\
Group (N)
\end{tabular}} & \multicolumn{4}{|c|}{13.5 days } & \multicolumn{4}{|c|}{14.5 days } \\
\hline & \multicolumn{2}{|c|}{$5 \mathrm{azaC}(7)$} & \multicolumn{2}{|c|}{ Control (8) } & \multicolumn{2}{|c|}{$5 \mathrm{azaC}(7)$} & \multicolumn{2}{|c|}{ Control (7) } \\
\hline & $\mathrm{N}$ & $\%$ & $\mathrm{~N}$ & $\%$ & $\mathrm{~N}$ & $\%$ & $\mathrm{~N}$ & $\%$ \\
\hline Bone & 7 & 100 & 7 & 87 & 6 & 85 & 7 & 100 \\
\hline Cartilage & 5 & 71 & 6 & 75 & 3 & 42 & 4 & 57 \\
\hline Myotubes & 2 & 28 & 3 & 37 & 0 & 0 & 0 & 0 \\
\hline Salivary glands & 3 & 42 & 6 & 75 & 3 & 42 & 5 & 71 \\
\hline Epidermis & 7 & 100 & 6 & 75 & 6 & 85 & 7 & 100 \\
\hline Hair follicles & 5 & 71 & 4 & 50 & 4 & 57 & 6 & 85 \\
\hline Sebacceous glands & 4 & 57 & 3 & 37 & 4 & 57 & 6 & 85 \\
\hline Adipose tissue & 4 & 57 & 5 & 71 & 5 & 71 & 5 & 71 \\
\hline
\end{tabular}

Note that no statistically significant difference was found.

plants. In 13.5-days old rat embryonic mandible transplants, all histological structures developed with no significant difference in the experimental and control group, although teeth were of a lower incidence in $5 \mathrm{azaC}$-treated transplants (Table 1).

However, in 14.5-days old transplants, the number of mandibular transplants in which teeth developed was significantly smaller in those treated with $5 \mathrm{azaC}$ when compared to the controls $(p=0,035)$. The rest of the histological structures showed no difference in the incidence between the experimental and control group of transplants (Table 2).

\section{DIsCusSION}

Our results have shown that the DNA-demethylating drug 5-azaC changed odontogenesis in transplanted embryonic mandibles. This result is in concordance with the general importance of DNA-methylation in development (8) and specifically in mammalian odontogenesis $(9,12)$. Since this DNA demethylating agent has been used in human medicine (30), it is crucial to be aware of its side effects upon embryonic development.

A higher global methylation and differential methylation level of gene promoters involved in development was found in patients with anodontia and hypodontia in comparison to healthy individuals (12). The results of this study have now shown that $5 \mathrm{azaC}$ diminished the potential for odontogenesis and enhanced differentiation of teeth in older (14.5-day-old) transplanted embryonic mandibles. Therefore, $5 \mathrm{azaC}$ seems to change odontogenesis in a stage-specific manner. 5azaC applied during pregnancy in the same strain of rats resulted in limb malformations of embryos treated on the $12^{\text {th }}$ and $13^{\text {th }}$ day of gestation, but not on the 14th day (31). Therefore, indi- vidual organs and histological structures have different sensitivity to $5 \mathrm{azaC}$, depending on the developmental stage. $5 \mathrm{azaC}$ is a DNA demethylating agent that changes spatiotemporal gene dynamics by activating gene promoters, and untimely gene expression of signalling molecules during the complicated process of odontogenesis may cause anomalies $(32,33)$. Recently it has been shown that DNA-demethylating activity of $5 \mathrm{azaC}$ is also associated with enhancement of ROS/RNS in limb buds that develop into malformed limbs (27). Tooth development proceeds also after birth when DNA methylation was shown to regulate odontogenesis through cell cycle inhibition (34).

DNA methylation is an epigenetic mechanism that mediates between the environment and the cells and tissues of a living organism (35). Some environmental factors, such as the osteogenic supplements (dexamethasone and chitosan), enhanced expression of dentin sialophosphoprotein and matrix extracellular phosphoglycoprotein for differentiation of dental pulp cells (7). Although in this particular case epigenetic signatures were not investigated, epigenetic approaches to the repair of dental pulp were recently proposed (36).

No impact of $5 \mathrm{azaC}$ on the differentiation of other histological structures, such as bone, cartilage, myotubes, salivary glands, epidermis, hair follicles, sebaceous glands, adipose cells was found in this study, so changes in epigenetic signatures seem not to play a vital role in the induction of these structures at these particular stages. Structure formation derived from mesenchyme depends upon prior interactions/cell crosstalk between the mesenchyme and maxillary or mandibular epithelia (37).

Embryonic mandible transplant survival and ongoing odontogenesis showed that this model of transplantation is appropriate for studying the development of teeth. The 
results confirm earlier positive findings of good survival rate and progression of differentiation in transplants of the rat embryonic epiglottis under the kidney capsule (25, 38).

In this study, the bell stage teeth have differentiated from the simple dental lamina structure, present in the isolated embryonic mandible (39). We found that the bell stage tooth germ structures were more differentiated in the 14.5-day-old mandibles than in 13.5-day-old mandibles. In 13.5-day-old mandibles proliferation marker (PCNA) was expressed only in a few odontoblasts. This suggests that most of the odontoblasts and all ameloblasts are postmitotic cells in the in vivo transplant, as well as is true for in situ odontogenesis (40). A postmitotic cell is a terminally differentiated one, so some odontoblasts were still undifferentiated. In 13.5 day-old transplants with only dentin production in the tooth crown, all odontoblasts seem not to have entered the terminal differentiation, thus disabling extensive enamel secretion induction in ameloblasts. Older transplants (14.5-day-old) were able to produce both dentin and enamel. Mezadri et al. (20) transplanted bell stage tooth germs from the newborn rats to an ectopic place, the skin pouch of the ear in an adult rat, which resulted in dentin secretion after seven days and dentin and enamel secretion after 14 days. Mezadri et al. (20) encompassed altogether the period of around 28-35 days from the beginning of gestation, while we encompassed 28.5-29.5 days. We can assume that the enamel production would be present even in the 13.5-dayold transplants if the in vivo cultivation lasted longer. Zhu et al. (22) showed that transplanting mice teeth already at the bell stage under the kidney capsule of adult mice leads to further development and differentiation up to 4 weeks in vivo, forming tooth crown, root, bone marrow, cementum-like tissue but longer transplantation period (up to 5 months) led to degeneration and forming of cystlike lesions. Transplanting autologous tooth germs was used to substitute individual teeth as early as the seventies in the last century (41). To understand how the methylation alterations affect the crosstalk between the cell and surrounding ectopic microenvironment (11) is also important for optimization of stem-cell-based teeth engineering (4). In 2007 dental buds were cultivated from interacting mouse epithelial and mesenchymal cells in a three-dimensional culture system in vitro. Transplanting such a bioengineered dental bud to the oral cavity of an adult rat resulted in the differentiation of a functional tooth with all structural elements $(42,43)$.

\section{CONCLUSIONS}

Although odontogenesis from the earliest primordium such as the dental lamina proceeded to the bell stage of both incisors and molars in several ectopic transplants of embryonic rat mandibles, only teeth from the older 14.5-day-old embryonic mandible produced dentine and enamel in transplants, while a day younger mandible transplants exerted restriction of development by not producing enamel. DNA-demethylating drug $5 \mathrm{azaC}$ restricted development of teeth in some of the transplanted mandibles (significantly in older ones) and impaired incidence of molars in transplants of both stages. At the same time, 5 azaC advanced morphogenesis of the tooth in older transplants in comparison to controls. Therefore, 14.5-day tooth-primordium seems to be more strictly regulated by epigenetic cues during odontogenesis. Our experimental results deepen the insight into the epigenetic causes of tooth agenesis and anomalies such as anodontia or hypodontia in mammal $(12,44)$ and may be important for tooth regeneration strategies.

Acknowledgements: This work was supported by the Croatian Ministry of Science, Education and Sport under Grant (No. 108-1080399-0335) "Experimental Embryonic Tumours and Development of Mammalian Embryo in vitro and in vivo"; University of Zagreb under Supportive Grants (No. 1.2.1.17, No.1101310 BM1.22) and Scientific Center of Excellence for Reproductive and Regenerative Medicine, Republic of Croatia, and by the European Union through the European Regional Development Fund, under grant agreement No. KK.01.1.1.01.0008, project "Reproductive and Regenerative Medicine - Exploring New Platforms and Potentials".

Conflict of interest: The authors report no conflict of interest. The authors alone are responsible for the content and writing of the study.

Author contributions: VR designed the research, conducted experiments and interpreted results; MHP designed, supervised and conducted histological assessments and statistical analysis; $A K B$ designed, supervised and conducted histological assessments and statistical analysis; $M T$ conducted histological analysis; NS designed and conducted in vivo experiments; GJ-L conducted histological analysis and interpretation of results; DJ conducted histological analysis and interpretation of results; FB-J designed, supervised the research and interpreted the results. All authors participated in writing the article.

\section{REFERENCES}

1. MOORE KL, PERSUAD TVN 2008 The developing human. In: Moore KL (ed) Clinically Oriented Embryology, $8^{\text {th }}$ ed. Saunders, Philadelphia, p 160-195

2. BARRESI MJF, GILBERT SF 2020 Developmental Biology, $12^{\text {th }}$ ed. Sinauer Associates, Oxford University Press, New York, USA

3. SADLER TW 2012 Langman's medical embryology. In: Sadler TW, Langman J (ed) Wolters Kluwer Health/Lippincott Williams \& Wilkins, Philadelphia, p 280-284

4. YEN AH, SHARPE PT 2008 Stem cells and tooth tissue engineering. Cell Tissue Res 331: 359-372. http://doi.org/10.1007/s00441-007-0467-6

5. YILDIRIM S 2013 Tooth development. In: Dental Pulp Stem Cells. SpringerBriefs in Stem Cells. Springer, New York, NY. 
https:/link.springer.com/chapter/10.1007\%2F978-1-4614-56872 2\#citeas)

6. HANSON A 2006 History of the Norway rat (Rattus norvegicus). Rat behavior and biology. http://www.ratbehavior.org/history.htm

7. ELASHRY SH, ABU-SEIDA AM, EMARA RA 2016 The influence of addition of osteogenic supplements to mineral trioxide aggregate on the gene expression level of odontoblastic markers following pulp capping in dogs. Vet Arhiv 86: 685-697

8. ŠERMAN A, VLAHOVIĆ M, ŠERMAN LJ, BULIĆ-JAKUŠ F 2006 DNA methylation as a regulatory mechanism for gene expression in mammals. Coll Antropol 30: 665-671

9. SU Y, FAN Z, WU X, LI Y, WANG F, ZHANG C, WANG J, DU J, WANG S 2016 Genome-wide DNA methylation profile of developing deciduous tooth germ in miniature pigs. BMC Genomics 17: 134. http://doi.org/10.1186/s12864-016-2485-9

10. PERDUCA V, OMICHESSAN H, BAGLIETTO L, SEVERI G 2018 Mutational and epigenetic signatures in cancer tissue linked to environmental exposures and lifestyle. Curr Opin Oncol 30: 61-67. http://doi.org/10.1097/CCO.0000000000000418

11. FADDA A, GENTILINI D, MOI L, BARAULT L, LEONI VP, SULAS P, ZORCOLO L, RESTIVO A, CABRAS F, FORTUNATO F, ZAVATTARI C, VARESCO L, GISMONDI V, DE MIGLIO MR, SCANU AM, COLOMBI F, LOMBARDI P, SAROTTO I, LOI E, LEONE F, GIORDANO S, DI NICOLANTONIO F, COLUMBANO A, ZAVATTARI P 2018 Colorectal cancer early methylation alterations affect the crosstalk between cell and surrounding environment, tracing a biomarker signature specific for this tumor. Int J Cancer 143: 907-920.

http://doi.org/10.1002/ijc.31380

12. WANG J, SUN K, SHEN Y, XU Y, XIE J, HUANG R, ZHANG Y, XU C, ZHANG X, WANG R, LIN Y 2016 DNA methylation is critical for tooth agenesis: implications for sporadic non-syndromic anodontia and hypodontia. Sci Rep 6: 19162. http://doi.org/ 10.1038/srep19162

13. PLAZIBAT M, KATUŠIĆ BOJANAC A, HIMERLEICH PERIĆ M, GAMULIN O, RAŠIĆ M, RADONIĆ V, ŠKRABIĆ M, KRAJAČIĆM, KRASIĆ J, SINČIĆ N, JURIĆ-LEKIĆ G, BALARIN M, BULIĆ-JAKUŠ F 2020 Embryo-derived teratoma in vitro biological system reveals antitumor and embryotoxic activity of valproate. FEBS J http://doi.org/10.1111/febs.15248 [Epub ahead of print]

14. BULIC-JAKUS F, KATUSIC BOJANAC A, JURIC-LEKIC G, VLAHOVIC M, SINCIC N 2016 Teratoma: from spontaneous tumors to the pluripotency/malignancy assay. Wiley Interdiscip Rev Dev Biol 5:186-209. http://doi.org/10.1002/wdev.219

15. LEVAK-SVAJGER B, KNEZEVIC V, SVAJGER A 1991 Development of separated germ layers of rodent embryos on ectopic sites: a reappraisal. Int J Dev Biol 35:177-189

16. BULIĆ-JAKUS F, ULAMEC M, VLAHOVIĆ M, SINCIĆ N, KATUSIĆ A, JURIĆ-LEKĆ G, SERMAN L, KRUSLIN B, BELICZA M 2006 Of mice and men: teratomas and teratocarcinomas. Coll Antropol 30: 921-924

17. CONWAY AE, LINDGREN A, GALIC Z, PYLE AD, WU H, ZACK JA, PELLIGRINI M, TEITELL MA, CLARK AT 2009 A self-renewal program controls the expansion of genetically unstable cancer stem cells in pluripotent stem cell-derived tumors. Stem Cells 27:18-28. http://doi.org/10.1634/stemcells.2008-0529

18. JURIĆ-LEKIĆ G, ŠVAJGER A 1989 Lentoid formation in ectopic grafts of lentectomised eyes of rat foetuses. Cell Differ Dev 27: 225-231

19. KATUSIĆ A, JURIĆ-LEKIĆ G, JOVANOV-MILOSEVIĆ N, VLAHOVIĆ M, JEZEK D, SERMAN L, SINCIĆ N, VELJANOVSKA B, BULIĆ-JAKUS F 2008 Development of the fetal neural retina in vitro and in ectopic transplants in vivo. Coll Antropol 32: 201-207
20. MEZADRI TJ, RIVERO-TAMES D, BOABAID F, ARMENGOL JA 2004 Development of tooth germ heterotopically grafted within the ear skin. An histological study in the rat. Med Oral 9: 243-252

21. XIE RY, YANG PS, LI S 2006 A histological innovative study of $\mathrm{Balb} / \mathrm{c}$ mouse tooth germ transplanted to nude mouse in vivo. Shanghai J Stom 15:378-382

22. ZHU EX, XIAO J, LIU TJ, JIANG WW, TAKAGI M 2000 Different histogenesis of experimental odontogenic cysts by the renal subcapsular transplantation of tooth germs of mice. Oral Medicine \& Pathology 5: 83-86. http://doi.org/10.3353/omp.5.83

23. KATUŠIĆ A, ŠERMAN LJ, BULIĆ-JAKUŠ F, JURIĆ-LEKIĆ G, VLAHOVIĆ M, KRATOCHWIL K 2004 The expression of proliferating cell nuclear antigen and retinoblastoma protein in transplanted fetal rat lacrimal gland. Acta Clin Croat 43: 211-215

24. GOSDEN RG 2008 Ovary and uterus transplantation. Reproduction 136: 671-680. http://doi.org/10.1530/REP-08-0099

25. MARINOVIC-KULISIC S, JURIC-LEKIC G, VIKIC-TOPICM, LOKOSEK V, RADUJKOVIC V, BULIC-JAKUS F, KATUSIC A, VLAHOVIC M, SERMAN L, SINCIC N 2011 5-azacytidine enhances proliferation in transplanted rat fetal epiglottis. Front Biosci 3: 581-590. http://doi.org/10.2741/e271

26. SERMAN L, VLAHOVIĆ M, SIJAN M, BULIĆ-JAKUS F, SERMAN A, SINCIĆ N, MATIJEVIĆ R, JURIĆ-LEKIĆ G, KATUSIĆ A 2007 The impact of 5-azacytidine on placental weight, glycoprotein pattern and proliferating cell nuclear antigen expression in rat placenta. Placenta 28: 803-811. http://doi.org/10.1016/j.placenta.2007.04.001

27. SOBOČAN N, KATUŠIĆ BOJANAC A, SINČIĆ N, HIMELREICH-PERIĆ M, KRASIĆ J, MAJIĆ Ž, JURIĆ-LEKIĆ G, ŠERMAN L, VLAHOVIĆ M, JEŽEK D, BULIĆ-JAKUŠ F 2019 A free radical scavenger ameliorates teratogenic activity of a DNA hypomethylating hematological therapeutic. Stem Cells Dev 28: 717-733. http://doi.org/10.1089/scd.2018.0194

28. MUZIC V, KATUSIC BOJANAC A, JURIC-LEKIC G, HIMELREICH M, TUPEK K, SERMAN L, MARN N, SINCIC N, VLAHOVIC M, BULIC-JAKUS F 2013 Epigenetic drug 5-azacytidine impairs proliferation of rat limb buds in an organotypic model-system in vitro. Croat Med J 54: 489-495. http://doi.org/10.3325/cmj.2013.54.489

29. COOK HC 1974 Manual of Histological Demonstration Techniques. Butterworth, London.

30. FLOTHO C, SOMMER S, LÜBBERT M 2018 DNA-hypomethylating agents as epigenetic therapy before and after allogeneic hematopoietic stem cell transplantation in myelodysplastic syndromes and juvenile myelomonocytic leukemia. Semin Cancer Biol 51: 68-79. http://doi.org/10.1016/j.semcancer.2017.10.011

31. VLAHOVIĆ M, BULIĆ-JAKUŠ F, JURIĆ-LEKIĆ G, FUČIĆ A, MARIĆ S, ŠERMAN D 1999 Changes in the placenta and in the rat embryo caused by demethylating agent 5 -azacytidine. Int J Dev Biol 43:843-846

32. WUX, LI Y, WANG F, HU L, LI Y, WANG J, ZHANG C, WANG S 2017 Spatiotemporal expression of Wnt/囚-catenin signaling during morphogenesis and odontogenesis of deciduous molar in miniature pig. Int J Biol Sci 13: 1082-1091. http://doi.org/10.7150/ijbs.20905

33. WAN M, LI H, ZHOUY, DU W, XU X, YE L, ZHOUX, ZHENG L 2018 DNA methylation: a frontier in tooth organogenesis and developmental dental defects. Curr Stem Cell Res Ther 13: 151-158. http://doi.org/10.2174/1574888X13666171206124940

34. LI Q, GUO Y, YAO M, LI J, CHEN Y, LIU Q, CHEN Y, ZENG Y, JI B, FENG Y 2018 Methylation of Cdkn1c may be involved in the regulation of tooth development through cell cycle inhibition. J Mol Histol 49: 459-469. http://doi.org/10.1007/s10735-018-9785-0 
35. BULJUBAŠIĆ R, BULJUBAŠIĆ M, BOJANAC AK, ULAMEC M, VLAHOVIĆ M, JEŽEK D, BULIĆ-JAKUŠ F, SINČIĆ N 2018 Epigenetics and testicular germ cell tumors. Gene 661: 22-33. http://doi.org/10.1016/j.gene.2018.03.072

36. KEARNEY M, COOPER PR, SMITH AJ, DUNCAN HF 2018 Epigenetic approaches to the treatment of dental pulp inflammation and repair: opportunities and obstacles. Front Genet 9: 331. http://doi.org/10.3389/fgene.2018.00311

37. HALL BK 1981 The induction of neural crest-derived cartilage and bone by embryonic epithelia: an analysis of the mode of action of an epithelial-mesenchymal interaction. J Embryol Exp Morph 64: 305-320

38. MARINOVIĆ KULIŠIĆ SM, JURIĆ-LEKIĆ G, BULIĆ-JAKUŠ F, RADUJKOVIĆ V, PARČETIĆ I, VLAHOVIĆ M, KATUŠIĆ A, SINČIĆ N, ŠERMAN L 2008 Development of epithelia in the ectopic transplant of fetal rat epiglottis. Acta Dermatovenerol Croat 16:55-59

39. RUGH R 1968 The mouse: Its Reproduction and Development, $10^{\text {th }}$ ed, Lippincott Williams and Wilkins, Minneapolis
40. BATH-BALOGH M, FEHRENBACH MJ 1997 Tooth development and eruption. In: Dolan J (ed) Illustrated Dental Embryology, Histology and Anatomy. W. B. Saunders Company, Philadelphia, p $49-76$

41. FILIPOVIĆ ZORE I, JURIĆ H, KOMAR D 2008 In the era of implant dentistry: did we forget own teeth buds? Acta Stomatol Croat 42: 97

42. NAKAO K, MORITA R, SAJI Y, ISHIDA K, TOMITA Y, OGAWA M, SAITOH M, TOMOOKA Y, TSUJI T 2007 The development of a bioengineered organ germ method. Nat Methods 4: 227-230. http://doi.org/10.1038/nmeth1012

43. OSHIMA M, TSUJI T 2014 Whole tooth regeneration using a bioengineered tooth. In: Hibi H, Ueda M (ed) New Trends in Tissue Engineering and Regenerative Medicine - Official Book of the Japanese Society for Regenerative Medicine. InTech, Rijeka p 109-119

44. MATALOVA E, FLEISCHMANNOVA J, SHARPE PT, TUCKER AS 2008 Tooth agenesis: from molecular genetics to molecular dentistry. J Dent Res 87: 617-23.

http://doi.org/10.1177/154405910808700715 